\title{
The Use of the Instagram Application as Educational Media on "Jingle Covid Education Challenge" Activities in West Java
}

\author{
Fensy Sella*, Yudi Sukmayadi \\ Department of Music Education \\ Universitas Pendidikan Indonesia \\ Bandung, Indonesia \\ *fensysella@upi.edu
}

\begin{abstract}
The study discussed how the role of the Instagram application as a music educational media in audiovisual jingle covid-education challenge activities in west Java. Audiovisual jingle cheng education challenge brings audiences to Instagram with more than a thousand participants, including Senior High school, vocational School, and Special school. In this jingle category, students should be able to compose songs, compose simple songs, and write lyrics that describe covid education. The action of the race is not just to get many individuals to respond to the current pandemic conditions, but it is also one of the student building efforts. In cutting up educational media on Instagram, researchers use qualitative descriptive research methods because they are based on the observations of objects and events that take place today. Data sources are acquired directly with field research online and data analysis. The findings from this study are to produce how Instagram role as member teaching in the center of covid-19 as well as how the use of the Instagram application as a music education media in audiovisual jingle covid-education challenge in west Java is called for.
\end{abstract}

Keywords-Instagram applications, music education media, covid education challenge

\section{INTRODUCTION}

According to Oemar Hamalik, learning media are tools, methods, and techniques used in order to more effectively communicate and interact between teachers and students in the education and teaching process at school [1]. One of the educational media that can be used by students is online media. Instagram is a popular application that is quite close to students. This application is often a medium of education for students. Instagram, which is growing so rapidly with its visual features, is the main attraction for social media users. Various photos and videos are uploaded with various themes ranging from self-portraits, food, hobbies, scenery, and with various editing techniques, as if each user is competing to make the most interesting feeds among the others.

It cannot be denied that Instagram has now become one of the "open photo albums" that allows people to be influenced by photos uploaded to an Instagram account. As written by Boyd and Elison in their journal entitled "Social Network Sites: Definition, History and Scholarship", social media is a unique thing, because social media allows users to articulate and make other people see their social networks. This can result in relationships between individuals that are not otherwise contrived, and create latent connections for users who know each other in the offline world [2]

In order to prevent the spread of COVID-19 in education units in West Java, all teaching and learning activities are carried out at the homes of each student. While studying at home, students are encouraged to study various materials related to Covid-19 guided by teachers who are competent in their fields. Participants are expected to be able to become educational agents for changes in handling Covid-19 in Indonesia. Therefore, the Regional Government of West Java Province through the West Java Education Office held the West Java CovEducation Challenge with the theme "West Java Response Corona" this activity involved high school, vocational and special school students throughout West Java. With this innovation and creativity, the results of learning activities will be more easily accepted by the community, especially in West Java, Indonesia.

This activity was attended by thousands of Senior High school, vocational School, and Special school. students from all over West Java. The purpose of this activity is:

- Through the concept of storytelling through videos and arrangements in this jingle competition, students are expected to be able to become educational agents of change in handling Covid-19 in Indonesia

- Students are able to design simple information media about the stages of handling the corona virus through song lyrics

- Encourage students to think critically about relevant issues that occur in the school environment, West Java Province, Indonesia, and the world. 
- Increase self-confidence in singing and acting in front of the camera.

Through the concept of telling stories through videos and arrangements in this jingle competition, students are expected to be able to become educational agents for changes in handling Covid-19 in Indonesia. Students are able to design simple information media about the stages of handling the corona virus through song lyrics. Encourage students to think critically about relevant issues that occur in the school environment, West Java Province, Indonesia, and the world. Increase self-confidence in singing and acting in front of the camera.

In this case, students are required to be active in making lyrics, simple arrangements with existing instruments at home, utilizing household tools as musical instruments, and being able to pack the song in just 1 minute. This activity also combines several subjects at school, namely Music, Indonesian, and Natural Sciences because it has elements of musical arrangement in it, good language for a jingle and knowledge of Covid-19. This teaching activity is not only a race against the existing curriculum or instructions in schools. In fact, some schools require students to take part in this challenge as a learning application in schools. Thus, researchers can see the responses of students and teachers in West Java in the Audiovisual Jingle Covid-Education Challenge in West Java and what are the implications of these activities? Does Instagram have a big influence as a medium of education?

\section{LITERATURE REVIEW}

According to Arsyad, teachers, text books, and the school environment are media. More specifically, the meaning of media in the teaching and learning process tends to be defined as graphic, photographic, or electronic tools to capture, process, and reconstruct visual and verbal information [3]. The Association for Education and Communication Technology (AECT) defines media as all forms that are used for an information distribution process. While the Education Association (NEA) defines as objects that can be manipulated, seen, heard, read or discussed along with instruments that are used properly in teaching and learning activities, can affect the effectiveness of instructional programs.

The contribution of learning and educational media according to Kemp and Dayton, namely [4]:

- Delivery of learning messages can be more standardized.

- Learning can be more interesting

- Learning becomes more interactive by applying learning theory

- The learning implementation time can be shortened

- The quality of learning can be improved
- The learning process can take place whenever and wherever needed.

- Students' positive attitudes towards learning materials and the learning process can be improved.

- The teacher's role changes in a positive direction.

Media in an educational perspective is a very strategic instrument in determining the success of the teaching and learning process. Because its existence can directly provide its own dynamics to students. With their limitations, humans are often less able to capture and respond to things that are abstract or that have never been recorded in their memory. To bridge the process of internalizing such teaching and learning, educational media are needed that clarify and make it easier for students to capture the educational messages conveyed. Therefore, the more students are presented with various supporting media and infrastructure, the more likely it is that educational values can be absorbed and digested. According to Scott, the definition of social media is "Social media provide the way people share ideas, content, thoughts, and online relationships [5]. Social media differ from so-called mainstream media in that anyone can create, can take the form of text, audio, video, images, and communities. "Which means, "Social media provides a way for people to share ideas, content, thoughts and relationships online. Social media is different from the so-called ordinary media where anyone can create it, make it in the form of text, video, image or community. "Instagram is a social application that is popular among smartphone users. The name Instagram is taken from the word 'Insta' which originates from 'Instant' and 'gram' from the word 'telegram'. 1 So Instagram is a combination of the words Instant-Telegram.

From the use of the word, it can be interpreted as an application for sending information quickly, namely in the form of photos or videos.

\section{METHODS}

This research was conducted using a qualitative approach. The qualitative approach in its implementation is adapted to the nature and reality of the problem and the objectives of the research. Therefore, by using a qualitative approach, it is hoped that it can solve various problems in the research. The data obtained in this study came from observations, observations, interviews and other relevant data carried out by the author as a research instrument. In addition to the descriptions that have been described above, research using this qualitative approach, when viewed from the various problems and data to be studied, this research is more natural (naturalistic).

\section{RESULTS AND DISCUSSION}

The Role of Instagram's Social Media According to Diamond, Instagram has many features in common like other popular social networks [6]. The added value is that we can share the photos to almost any other major social network. Here are some of the features you'll find on Instagram that are 
also popular on most social media platforms according to others:

- Hashtag (hashtag) Create a hashtag for a company, 'see also what other people use to attract other followers who have similar interests. The best thing is to create a hashtag of a company because the product community can find it easier, competition activities or challenges such as West Java CovEducation

- Automatic notification (push notification) This notification notifies people who view or comment on a photo of an account. To set it up, you have to enter the settings page on your phone.

- Activity source tag and location Marketers can enter the location of the photo when they upload it so that the photo can be identified with a certain area and can be searched using that location.

- Video contests, music contests and other competitions are easily presented via Instagram.

The Jabar Covid Education Challenge Audiovisual Jingle competition was able to attract Instagram users with more than a thousand participants including Senior High school, vocational School, and Special school. In this jingle category, students must be able to make songs, make simple arrangements, and make lyrics that contain Covid Education. After watching, examining, evaluating, the works of adolescents, which are quite a lot, there is a belief that the potential of high school students and the equivalent of West Java Province in the field of multimedia is very large. This competition activity is of course not only to invite many parties to respond to the conditions of the pandemic that is currently happening, but also to become an effort to foster students.

The type of competition that is being held is of course very interesting for today's youth generation, namely the Audio Visual Jingle Competition. Today's generation is Generasai Selfie, lay generation, internet generation, virtual generation, etc. which has been so popular in recent years is indeed very firmly linked to today's rapidly developing tools and social media. Competitions like this are certainly very suitable for them, apart from being able to appear (selfie) in front of many virtual viewers, they can also work and are required to have a critical power towards problems in their surrounding environment, they are also required to be able to solve many problems faced with creative power. tall one.

The audiovisual challenge of the jingle is judged in terms of arrangement, melody lyrics and arrangements must be original, not plagiarism or quoted from other jingles, the lyrics must contain the word West Java Cov-Education and do not contain discrimination or offend certain parties, maximum duration of 60 seconds and sung in individual. Then uploaded via the Instagram application with the hashtag jabar cov-education challenge. This activity can also combine several subjects because in it there is an element of creativity in using language, editing a video, knowledge about Covid 19, and learning experiences using the Instagram application.

\section{CONCLUSION}

Based on the results of data analysis, it can be concluded that Intagram gives students the authority to create their own digital content and publish it online, besides that it can stimulate the activeness of students and educators in teaching. The Jingle Covid Education Challenge "activity in West Java utilizes an Instagram application which aims to make students expected to be able to become educational agents of change in handling Covid-19 in Indonesia and Encourage students to think critically about relevant issues that occur in the school environment, West Java Province, Indonesia, and the world. The use of Instagram as an educational medium is expected to be able to prepare itself to welcome the 4.0 industrial revolution, one of which can be directly felt is the use of technology in all environments, so that the use of social media, especially Instagram, is seen as one step to inviting a new era.

\section{REFERENCES}

[1] O. Hamalik, Educational Media. Bandung: Citra Aditya, 1989.

[2] D.M. Boyd and N.B. Ellison, "Social network sites: Definition, history, and scholarship," Journal of computer-mediated communication, vol. 13, no. 1, pp. 210-230, 2007.

[3] A. Arsyad, Media Pengajaran. Jakarta: Raja Grafindo Persada, 1997.

[4] J.E. Kemp and D.K. Dayton, Planning and Producing Instructional Media. Cambridge: Harper and Row Publishers New York, 1985.

[5] J. Scott, Social Network Analysis. 3rd ed. London: sage, 2013.

[6] S. Diamond, The Visual Marketing Revolution: 26 Kuat Sukses Pemasaran di Media Sosial. Jakarta: PT Serambi Ilmu Semesta, 2015. 